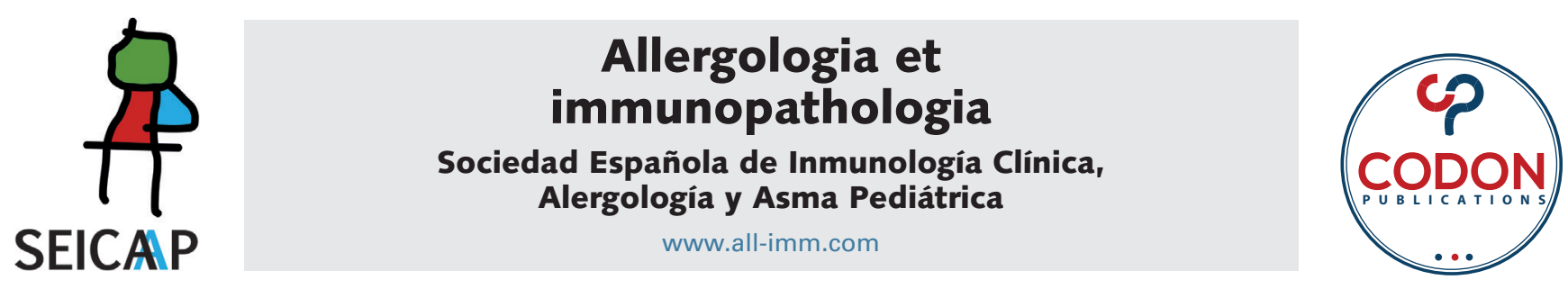

ORIGINAL ARTICLE

\title{
Association of PTPN22 single nucleotide polymorphisms with chronic spontaneous urticaria
}

\author{
Maryam Sadra, Neda Khalilib,c, Bahareh Mohebbia, Banafsheh Mosharmovaheda, \\ Parivash Afradia , Nima Rezaei ${ }^{\mathrm{b}, \mathrm{c}, \mathrm{d} *}$
}

\begin{abstract}
aMolecular Immunology Research Center, Children's Medical Center, Tehran University of Medical Sciences, Tehran, Iran ${ }^{b}$ Research Center for Immunodeficiencies, Children's Medical Center, Tehran University of Medical Sciences, Tehran, Iran 'Network of Immunity in Infection, Malignancy and Autoimmunity (NIIMA), Universal Scientific Education and Research Network (USERN), Tehran, Iran

${ }^{d}$ Department of Immunology, School of Medicine, Tehran University of Medical Sciences, Tehran, Iran
\end{abstract}

Received 7 August 2020; Accepted 12 September 2020

Available online 1 March 2021

\author{
KEYWORDS \\ urticaria; \\ gene polymorphism; \\ PTPN22; \\ chronic spontaneous \\ urticaria
}

\begin{abstract}
Introduction and objectives: Chronic spontaneous urticaria (CSU) is thought to be an autoimmune disease in a subpopulation of patients. Protein tyrosine phosphatase-22 (PTPN22) polymorphisms are considered to be one of the strongest contributing factors to autoimmune diseases. In this study, we aimed to investigate the potential association of several PTPN22 single nucleotide polymorphisms (SNPs) with CSU in an Iranian population.

Material and methods: A total of 93 CSU patients and 100 healthy individuals were included in this study. Five SNPs within the PTPN22 gene were analyzed using TaqMan genotyping assays. The frequency of alleles, genotypes, and haplotypes of PTPN22 SNPs (rs12760457, rs2476601, rs1310182, rs1217414, and rs33996649) was investigated.

Results: A significantly higher prevalence of the rs1310182 $\mathrm{T}$ allele was observed among patients compared with controls [OR $=1.75(95 \% \mathrm{Cl}$ : 1.17-2.63); $\mathrm{P}=0.007]$. In addition, the rs1310182 CC genotype and TT genotype were 0.47 and 2.06 times more common in patients, respectively $(P=0.03)$. Moreover, haplotype analysis demonstrated that CGCGC, CGTGC, and TGCGC $(P<0.001)$ were significantly associated with CSU. No significant differences were observed between the patients and controls in the other analyzed PTPN22 SNPs.

Conclusions: Polymorphisms of the PTPN22 gene are associated with an increased susceptibility to CSU in the studied Iranian population.

(c) 2021 Codon Publications. Published by Codon Publications.
\end{abstract}

*Corresponding author: Nima Rezaei, MD, PhD. Children’ Medical Center Hospital, Dr. Gharib St, Keshavarz Blvd, Tehran, Iran. Email address: rezaei_nima@tums.ac.ir 


\section{Introduction}

Urticaria, generally known as hives, is a common mast-cell driven disease that is characterized by the development of wheals, angioedema, or both. Urticaria is classified by its duration and the involvement of eliciting factors; chronic spontaneous urticaria (CSU) is defined as the presence of wheals, angioedema, or both for at least 6 weeks that is not provoked by any specific factor. ${ }^{1}$ Urticaria affects between 15 and $25 \%$ of the population at some point during their life, which is most often acute. ${ }^{2,3}$. Chronic urticaria has a prevalence of $0.1-3 \%$ among the general population and is associated with a marked decrease in the quality of life of patients. ${ }^{4-7}$ This condition tends to be more common among adults and is more commonly observed in women than in men. ${ }^{8}$ Although an exogenous trigger is often found in patients with inducible urticaria (such as cold, heat, delayed pressure, etc.), the etiopathogenesis of spontaneous urticaria is not well understood. ${ }^{9}$ Currently, autoimmunity is thought to play an important role in the etiology of chronic spontaneous urticaria. ${ }^{3,10,11}$ Studies have reported that in approximately $30-50 \%$ of patients with chronic urticaria it has an autoimmune origin, with IgE autoantibodies against auto-allergens or functional IgG autoantibodies against IgE or the high-affinity IgE receptor FccRla detected in patients' sera. ${ }^{3,12}$ Other possible causes of CSU that have been proposed in different studies include pseudo-allergy (non-allergic hypersensitivity reactions) to foods or drugs, and acute or chronic infections.1,13,14

A relationship between CSU and autoimmune diseases has been established ${ }^{9}$; a considerable percentage of CSU patients have antithyroid, antimitochondrial, and antinuclear antibodies. Other autoimmune diseases associated with chronic urticaria include vitiligo, pernicious anemia, and insulin-dependent diabetes mellitus..$^{11,15,16}$ In addition, one study reported that chronic urticaria may have an increased prevalence among those with a positive family history, ${ }^{17}$ suggesting a possible role for genetic factors. ${ }^{18,19}$

Protein tyrosine phosphatase N22 (PTPN22) encoded by the PTPN22 gene, located on chromosome 1p13.3-13.1, is a lymphoid-specific phosphatase (Lyp) that regulates T-cell activation. It is currently considered as one of the strongest contributing factors to autoimmunity, along with major histocompatibility complex (MHC). Several studies have shown that polymorphisms of PTPN22 are linked to the development of autoimmune diseases such as Graves' disease, Hashimoto's thyroiditis (HT), rheumatoid arthritis (RA), type 1 diabetes mellitus (T1DM), systemic lupus erythematosus (SLE), vitiligo, and progressive systemic sclerosis. ${ }^{20-25}$ The $1858 \mathrm{C} / \mathrm{T}$ variant, which is the main autoimmune-related polymorphism, causes a change in the function of Lyp and thus encodes a protein that cannot bind to the protein tyrosine kinase Csk. ${ }^{24}$

A previous study that investigated the rs2488457C, rs1310182T, and rs3811021T polymorphisms in a Polish population with CSU revealed that the CTT haplotype was significantly associated with this disease. ${ }^{9}$ Herein, we aimed to investigate the potential association of several single nucleotide polymorphisms (SNPs) of the PTPN22 gene with chronic spontaneous urticaria in an Iranian population.

\section{Material and methods}

\section{Study population}

A total of 93 patients diagnosed with CSU, who had been referred to the Children's Medical Center, the Pediatrics Center of Excellence in Tehran, Iran, were enrolled in the study.

The diagnosis of CSU was made based on the EAACl/ $\mathrm{GA}^{2}$ LEN/EDF/WAO guidelines of urticaria ${ }^{1}$ after taking a detailed medical history, performing physical examination, and, when indicated, performing diagnostic serological tests. Other possible differential diagnoses, such as inducible urticaria, urticarial vasculitis, urticaria pigmentosa, and Schnitzler's syndrome were excluded with the consideration of this diagnostic workup. Patients who had any other underlying disease were not included in the study. The control group comprised 100 healthy individuals with no known history of any autoimmune or systemic disease. The racial background of all included participants was Iranian.

This study was approved by the Ethics Committee of Tehran University of Medical Sciences, and all subjects were given written informed consent before participation in the study.

\section{Blood sampling and genotyping of PTPN22 SNPs}

Blood samples were obtained from all patients and controls in EDTA-coated tubes, and stored at $-20^{\circ} \mathrm{C}$ until further processing. Genomic DNA from 3-5 mL of peripheral blood was extracted by using the phenol-chloroform protocol. ${ }^{26}$ SNP genotyping was performed by real-time polymerase chain reaction (RT-PCR) using allelic discrimination TaqMan genotyping assays (ABI Applied Biosystems, 7300 Real-Time PCR System, USA) based on the manufacturer's protocol. According to pre-designed primers (Table 1), the following PTPN22 SNPs (rs12760457, rs2476601, rs1310182, rs1217414, and rs33996649) were investigated and recorded.

\section{Statistical analysis}

Allele, genotype, and haplotype frequencies were reported as number (percentage), and the differences between cases and controls were assessed via chi-square test. The odds ratio $(\mathrm{OR})$ and $95 \%$ confidence interval $(\mathrm{Cl})$ were measured for each allele and genotype. All statistical analyses were performed using the Epi-Info statistical software (version 7.2.0.1, World Health Organization, Geneva, Switzerland). P-value of less than 0.05 was considered to be statistically significant.

\section{Results}

\section{Allele and genotype frequencies}

A significantly higher prevalence of the rs1310182 T allele was observed among patients compared with controls [OR = 1.75 (95\% Cl: 1.17-2.63); $\mathrm{P}=0.007]$, as demonstrated in Table 2. In addition, the rs1310182 CC genotype and TT genotype were 0.47 and 2.06 times more common in 
Table 1 PTPN22 SNPs and primers used in this study.

\begin{tabular}{|c|c|c|c|}
\hline PTPN22 gene & Location & Context sequence & SNP type \\
\hline rs12760457 & Chr.1: 113847126 & $\begin{array}{l}\text { TTTTCAATTCATTAATTCTTTTTTC[C/T] } \\
\text { GTACCCTCTATTCTGCTGTTGAACC }\end{array}$ & $\begin{array}{l}\text { Intron, transition substitution, } \\
\text { intragenic }\end{array}$ \\
\hline rs2476601 & Ch1: 113834946 & $\begin{array}{l}\text { ACCACAATAAATGATTCAGGTGTCC[A/G] } \\
\text { TACAGGAAGTGGAGGGGGGATTTCA }\end{array}$ & $\begin{array}{l}\text { Intron,miss-sense mutation,transition } \\
\text { substitution,intragenic }\end{array}$ \\
\hline rs1310182 & Chr.1: 113830881 & $\begin{array}{l}\text { TAAACAAACCCAATGACCAATGACA[C/G/T] } \\
\text { GTGAACCTCTTGTACTTTACTGCAT }\end{array}$ & $\begin{array}{l}\text { Transition substitution, intron, } \\
\text { UTR 3,intragenic }\end{array}$ \\
\hline rs1217414 & Ch1: 113870045 & $\begin{array}{l}\text { AAACCTTTGCCTCCTGGAGCTAACA[C/T] } \\
\text { TCTGGTACCGGATAGCAGATGTGAA }\end{array}$ & $\begin{array}{l}\text { Intron,transition } \\
\text { substitution,intragenic }\end{array}$ \\
\hline rs33996649 & Chr1: 113852067 & $\begin{array}{l}\text { TGAAGGCCTCTGTGTCCGCATTTCC[C/T] } \\
\text { GGATCAAACTGAAAACACTGAAGTT }\end{array}$ & Intron variant, missense \\
\hline
\end{tabular}

Table 2 PTPN22 gene allele and genotype polymorphisms in patients with chronic spontaneous urticaria and controls.

\begin{tabular}{|c|c|c|c|c|c|c|}
\hline SNP & $\begin{array}{c}\text { Allele/ } \\
\text { Genotype }\end{array}$ & $\begin{array}{c}\text { Cases }(n=93) \\
N(\%)\end{array}$ & $\begin{array}{c}\text { Controls }(n=100) \\
\text { N (\%) }\end{array}$ & P-value & OR & $95 \% \mathrm{Cl}$ \\
\hline \multirow[t]{5}{*}{ rs12760457 } & C & 130 (70.65) & 143 (71.5) & 0.73 & Reference & Reference \\
\hline & $\mathrm{T}$ & $54(29.34)$ & $54(27)$ & 0.73 & 1.10 & $0.70-1.71$ \\
\hline & $\mathrm{CC}$ & $48(52.17)$ & $54(54)$ & 0.77 & 0.90 & $0.51-1.60$ \\
\hline & $\mathrm{CT}$ & 34 (36.95) & $36(36)$ & 1.00 & 1.02 & $0.56-1.84$ \\
\hline & TT & $10(10.86)$ & $9(9)$ & 0.80 & 1.21 & $0.47-3.15$ \\
\hline \multirow[t]{5}{*}{ rs2476601 } & $A$ & $1(0.54)$ & 0 & 0.47 & - & - \\
\hline & G & $183(99.45)$ & $200(100)$ & 0.47 & Reference & Reference \\
\hline & AA & 0 & 0 & 1.00 & 0.00 & - \\
\hline & AG & 1 (1.08) & 0 & 0.47 & - & - \\
\hline & GG & 91 (98.91) & $100(100)$ & 0.47 & 0.00 & - \\
\hline \multirow[t]{5}{*}{ rs1310182 } & $\mathrm{C}$ & 80 (43.47) & 115 (57.5) & 0.007 & Reference & Reference \\
\hline & $T$ & $104(56.52)$ & 85 (42.5) & 0.007 & 1.75 & $1.17-2.63$ \\
\hline & $\mathrm{CC}$ & $18(19.56)$ & 34 (34) & 0.03 & 0.47 & $0.24-0.91$ \\
\hline & $\mathrm{CT}$ & $44(47.82)$ & 47 (47) & 1.00 & 1.03 & $0.58-1.82$ \\
\hline & TT & $30(32.60)$ & 19 (19) & 0.03 & 2.06 & $1.06-4.00$ \\
\hline \multirow[t]{5}{*}{ rs1217414 } & $A$ & $50(27.17)$ & $61(30.5)$ & 0.49 & Reference & Reference \\
\hline & $\mathrm{G}$ & 134 (72.82) & 137 (68.5) & 0.49 & 1.19 & $0.76-1.85$ \\
\hline & AA & $7(7.60)$ & 9 (9) & 0.79 & 0.82 & $0.29-2.30$ \\
\hline & AG & $36(39.13)$ & $43(43)$ & 0.56 & 0.83 & $0.47-1.49$ \\
\hline & GG & $49(53.26)$ & 47 (47) & 0.12 & 1.57 & $0.90-2.74$ \\
\hline \multirow{5}{*}{ rs33996649 } & $C$ & $183(99.45)$ & 198 (99) & 1.00 & 1.84 & $0.16-20.5$ \\
\hline & $\mathrm{T}$ & $1(0.54)$ & $2(1)$ & 1.00 & Reference & Reference \\
\hline & $\mathrm{CC}$ & 91 (98.91) & $98(98)$ & 1.00 & 1.85 & $0.16-20.8$ \\
\hline & $\mathrm{CT}$ & $1(1.08)$ & $2(2)$ & 1.00 & 0.54 & $0.04-6.76$ \\
\hline & TT & 0 & 0 & 0.49 & 0.00 & - \\
\hline
\end{tabular}

OR: odds ratio; $\mathrm{Cl}$ : confidence interval.

patients, respectively $(P=0.03)$. However, the allele and genotype frequencies of the other four investigated PTPN22 SNPs did not differ significantly between the patients and controls.

\section{Haplotype analysis}

Haplotype analysis demonstrated that CGCGC, CGTGC, and TGCGC $(P<0.001)$ were significantly associated with CSU (Table 3). Other haplotypes did not significantly increase susceptibility to chronic spontaneous urticaria.

\section{Discussion}

This study investigated five SNPs within the PTPN22 gene in Iranian patients with chronic spontaneous urticaria. Although the underlying mechanisms of chronic spontaneous urticaria are not well understood, genetic factors may be associated with its pathogenesis. ${ }^{17-19}$ The major genetic markers identified in chronic urticaria are genes related to mast cell activation and histamine and also those related to the arachidonic acid (AA) pathway, as well as other contributing genes such as PTPN22. ${ }^{18}$ Nevertheless, data on the role of the PTPN22 gene in 
Table 3 PTPN22 gene haplotype in patients with chronic spontaneous urticaria and controls.

\begin{tabular}{|c|c|c|c|c|c|}
\hline Haplotypea & $\begin{array}{c}\text { Cases }(n=93) \\
N(\%)\end{array}$ & $\begin{array}{c}\text { Controls }(n=100) \\
\text { N }(\%)\end{array}$ & P-value & OR & $95 \% \mathrm{Cl}$ \\
\hline CGCGC & $+56(60.2)$ & $+24(24)$ & $<0.001$ & 4.79 & $2.58-8.89$ \\
\hline CGCAC & $+22(23.6)$ & +33 (33) & 0.15 & 1.58 & $0.84-2.99$ \\
\hline CGTAC & $+28(30.1)$ & $+28(28)$ & 0.75 & 1.1 & $0.59-2.06$ \\
\hline CGTGC & $+23(24.7)$ & $0(0)$ & $<0.001$ & - & - \\
\hline TGTGC & +53 (56.9) & $+56(56)$ & 1.00 & 1.04 & $0.58-1.84$ \\
\hline CGTGT & +1 (1.07) & $0(0)$ & 1.00 & - & - \\
\hline TGCGC & $0(0)$ & $+53(53)$ & $<0.001$ & - & - \\
\hline CGCGT & $0(0)$ & $+2(2)$ & 1.00 & - & -- \\
\hline
\end{tabular}

ars12760457, rs2476601, rs1310182, rs1217414, rs33996649.

OR: odds ratio; $\mathrm{Cl}$ : confidence interval.

patients with urticaria is very scarce. Hence, we examined whether polymorphisms in this gene may contribute to CSU development. This study approved an association of the rs1310182 PTPN22 polymorphism with chronic spontaneous urticaria. We observed that patients with CSU had a higher risk of rs1310182 T allele carriage compared with controls. Moreover, three out of eight sequenced haplotypes were significantly associated with CSU (CGCGC, CGTGC, and TGCGC). In 2011, Brzoza et al. ${ }^{24}$ found that PTPN22 1858C/T did not increase susceptibility to chronic urticaria in a Polish population. However, 1 year later, the same authors reported that PTPN22 polymorphisms may contribute to CSU, after investigating three other SNPS (rs2488457C, rs1310182T, and rs3811021T). ${ }^{9}$

Studies have indicated that in a significant portion of patients with CSU it has an autoimmune origin. ${ }^{3,12}$ This hypothesis is supported by the evidence that IgG autoantibodies against IgE or the high-affinity IgE receptor FceRla are detected in the serum of up to $50 \%$ of patients with CSU. ${ }^{27,28}$ In addition, an association between CSU and autoimmune diseases has been established. Recent studies have shown that about 25, 27, and $29 \%$ of CSU patients have antithyroid, antimicrosomal, and antinuclear antibodies, respectively. ${ }^{9,11,15,16,29}$ On the other hand, many studies have confirmed that several specific polymorphisms of PTPN22 increase patients' susceptibility to autoimmune diseases, including RA, SLE, T1DM, Graves' disease, HT, vitiligo, and sclerosis. ${ }^{30-35}$ A study by Umemura et al. ${ }^{20}$ showed that polymorphisms in PTPN22 may have a protective role in susceptibility to autoimmune liver diseases in the Japanese population. Recently, Houcken et al. ${ }^{25}$ reported that the rs2476601 PTPN22 polymorphism is significantly associated with autoimmune polyglandular syndromes (APS), including T1DM and Graves' disease.

PTPN22 is a protein tyrosine phosphatase that causes inactivation of T-cells by dephosphorylating the protein tyrosine kinases involved in T-cell activation. ${ }^{36}$ Polymorphisms in this gene result in functional changes of Lyp, and thus lead to the overactivation of T-cells. However, some researchers have stated that the autoimmunity associated with PTPN22 polymorphisms is due to the increased threshold of T-cell activation, and subsequently, the survival of autoreactive T-cells in the thymus. ${ }^{37-39}$ While mast cells play the main role in chronic urticaria, there is evidence that CD4+ T-cells are highly activated in these patients. ${ }^{40}$ Although the relationship between T-cell activation and mast cell degranulation in CSU is not fully understood, the interaction of these immune cells residing in urticarial lesions may lead to degranulation, cytokine release, and secretion of matrix metalloproteinase (MMP)-9 by mast cells. ${ }^{41,42}$ MMP-9 is known to be involved in the transmigration of lymphocytes, eosinophils, and neutrophils to the skin. ${ }^{40}$ Furthermore, the production of IgG autoantibodies requires the initial activation of autoantigen-primed T-cells. ${ }^{43}$ This evidence further supports the findings of our study, which suggest a potential association of PTPN22 SNPs in patients afflicted with chronic spontaneous urticaria.

Currently, the mainstay of treatment in chronic urticaria is second-generation antihistamines. It is widely accepted that CSU patients of an autoimmune origin are more likely to be resistant to conventional treatments. Based on the literature, at least $50 \%$ of patients with autoimmune urticaria do not respond well to treatment with antihistamines and thus, require alternative therapies, including omalizumab, cyclosporine, corticosteroids, and plasmapheresis. ${ }^{1,44}$ Therefore, identifying such patients will help physicians in predicting patients' response to therapy and in the earlier prescription of alternative therapies, which would have a great impact on the quality of life of patients, as well as reducing the burden on health care systems.

One of the limitations of this study is that we did not assess the association between PTPN22 SNPs and disease activity in our patients. Another limitation is that IgG autoantibodies were not measured, so we cannot estimate the percentage of patients with a likely autoimmune origin. Although our study demonstrated a significant relationship between specific PTPN22 polymorphisms and chronic spontaneous urticaria, it is important to note that this study was conducted in a relatively small number of patients who were all from an Iranian racial background. Thus, the contribution of these polymorphisms in the development of CSU should also be investigated among other ethnicities and races. So far, autoimmunity-related serological tests are not implemented in the routine diagnostic workup of patients with CSU; however, if further comprehensive studies confirm the autoimmune origin of this disease, 
measuring the level of specific autoantibodies in patients' sera could be considered.

Conclusively, our study showed that polymorphisms of the PTPN22 gene are associated with an increased susceptibility to CSU in the Iranian population. Understanding the molecular mechanisms contributing to the development and progression of autoimmune diseases through genetic association studies will provide a platform for introducing new personalized diagnostic and therapeutic approaches.

\section{Declaration of interest}

All the authors declare that they have no conflict(s) of interest.

\section{Funding}

This work was supported by Tehran University of Medical Sciences [grant number 96-03-93-36505].

\section{References}

1. Zuberbier $T$, Aberer $W$, Asero $R$, Abdul Latiff $A H$, Baker $D$, Ballmer-Weber $B$, et al. The EAACl/GA²LEN/EDF/WAO guideline for the definition, classification, diagnosis and management of urticaria. Allergy. 2018;73:1393-1414. https://doi. org/10.1111/all.13397

2. Amar SM, Dreskin SC. Urticaria. Prim Care. 2008;35:141-157. https://doi.org/10.1016/j.pop.2007.09.009

3. McGirt LY, Vasagar K, Gober LM, Saini SS, Beck LA. Successful treatment of recalcitrant chronic idiopathic urticaria with sulfasalazine. Arch Dermatol. 2006;142:1337-1342. https://doi. org/10.1001/archderm.142.10.1337

4. Lapi F, Cassano N, Pegoraro V, Cataldo N, Heiman F, Cricelli I, et al. Epidemiology of chronic spontaneous urticaria: results from a nationwide, population-based study in Italy. Brit J Dermatol. 2016;174:996-1004. https://doi.org/10.1111/bjd.14470

5. Greaves M. Chronic urticaria. J Allergy Clin Immunol. 2000;105:664-672.https://doi.org/10.1067/mai.2000.105706

6. Gaig P, Olona M, Lejarazu D, Caballero T, Domínguez F, Echechipia S, et al. Epidemiology of urticaria in Spain. $J$ Investig Allergol Clin Immunol. 2004;14:214-220.

7. Grattan CEH, Borzova E. Urticaria, angioedema, and anaphylaxis. In: Rich RR, Fleisher TA, Shearer WT, Schroeder HW, Frew AJ, Weyand CM, editors. Clinical immunology. 5th edition. London: Elsevier; 2019. p. 585.e1-600.e1. https://doi. org/10.1016/B978-0-7020-6896-6.00042-9

8. Greaves MW. Chronic urticaria. NEJM. 1995;332:1767-1772. https://doi.org/10.1056/NEJM199506293322608

9. Brzoza Z, Grzeszczak W, Rogala B, Trautsolt W, Moczulski D. PTPN22 polymorphism presumably plays a role in the genetic background of chronic spontaneous autoreactive urticaria. Dermatology. 2012;224:340-345. https://doi.org/10.1159/ 000339332

10. Kanani A, Betschel SD, Warrington R. Urticaria and angioedema. Allergy Asthma Clin Immunol. 2018;14:59. https://doi.org/10.1186/s13223-018-0288-z

11. Poonawalla T, Kelly B. Urticaria: a review. Am J Clin Dermatol. 2009;10:9-21. https://doi.org/10.2165/0128071-20091001000002

12. Sabroe RA, Fiebiger E, Francis DM, Maurer D, Seed PT, Grattan CEH, et al. Classification of anti-Fc epsilon RI and
anti-IgE autoantibodies in chronic idiopathic urticaria and correlation with disease severity. J Allergy Clin Immunol. 2002;110:492-499. https://doi.org/10.1067/mai.2002.126782

13. Beck LA, Bernstein JA, Maurer M. A review of international recommendations for the diagnosis and management of chronic urticaria. Acta dermato-venereologica. 2017;97:149158. https://doi.org/10.2340/00015555-2496

14. Nettis E, Foti C, Ambrifi M, Baiardini I, Bianchi L, Borghi A, et al. Urticaria: recommendations from the Italian Society of Allergology, Asthma and Clinical Immunology and the Italian Society of Allergological, Occupational and Environmental Dermatology. Clin Mol Allergy. 2020;18. Article no. 8. https:// doi.org/10.1186/s12948-020-00123-8

15. Kikuchi Y, Fann T, Kaplan AP. Antithyroid antibodies in chronic urticaria and angioedema. J Allergy Clin Immunol. 2003;112:218. https://doi.org/10.1067/mai.2003.1605

16. Viswanathan RK, Biagtan MJ, Mathur SK. The role of autoimmune testing in chronic idiopathic urticaria. Ann Allergy Asthma Immunol. 2012;108:337.e1-341.e1. https://doi.org/ 10.1016/j.anai.2012.02.018

17. Asero R. Chronic idiopathic urticaria: a family study. Ann Allergy Asthma Immunol. 2002;89:195-196. https://doi. org/10.1016/S1081-1206(10)61937-0

18. Losol P, Yoo H-S, Park H-S. Molecular genetic mechanisms of chronic urticaria. Allergy Asthma Immunol Res. 2014;6:13-21. https://doi.org/10.4168/aair.2014.6.1.13

19. Konstantinou GN, Asero R, Ferrer M, Knol EF, Maurer M, Raap $U$, et al. EAACl taskforce position paper: evidence for autoimmune urticaria and proposal for defining diagnostic criteria. Allergy. 2013;68:27-36. https://doi.org/10.1111/all.12056

20. Umemura T, Joshita S, Yamazaki T, Komatsu M, Katsuyama Y, Yoshizawa K, et al. Genetic association of PTPN22 polymorphisms with autoimmune hepatitis and primary biliary cholangitis in Japan. Sci Rep. 2016;6:1-6. https://doi.org/10.1038/ srep29770

21. Budding K, Van Setten J, Van De Graaf EA, Van Rossum OA, Kardol-Hoefnagel T, Kwakkel-van Erp JM, et al. The autoimmune-associated single nucleotide polymorphism within PTPN22 correlates with clinical outcome after lung transplantation. Front Immunol. 2019;9:3105. https://doi.org/10.3389/ fimmu.2018.03105

22. Criswell LA, Pfeiffer KA, Lum RF, Gonzales B, Novitzke J, Kern $M$, et al. Analysis of families in the multiple autoimmune disease genetics consortium (MADGC) collection: the PTPN22 620W allele associates with multiple autoimmune phenotypes. Am J Hum Genet. 2005;76:561-571. https://doi. org/10.1086/429096

23. Velaga $M$, Wilson $V$, Jennings $C$, Owen $C$, Herington $S$, Donaldson $\mathrm{P}$, et al. The codon 620 tryptophan allele of the lymphoid tyrosine phosphatase (LYP) gene is a major determinant of Graves' disease. J Clin Endocrinol Metab. 2004;89:5862-5865. https://doi.org/10.1210/jc.2004-1108

24. Brzoza Z, Grzeszczak W, Trautsolt W, Moczulski D. Protein tyrosine phosphatase-22 (PTPN-22) polymorphism in the pathogenesis of chronic urticaria. Allergy. 2011;66:1392-1393. https://doi.org/10.1111/j.1398-9995.2011.02651.x

25. Houcken J, Degenhart C, Bender K, König J, Frommer L, Kahaly GJ. PTPN22 and CTLA-4 polymorphisms are associated with polyglandular autoimmunity. J Clin Endocrinol Metab. 2018;103:1977-1984. https://doi.org/10.1210/jc.2017-02577

26. Di Pietro F, Ortenzi F, Tilio M, Concetti F, Napolioni V. Genomic DNA extraction from whole blood stored from 15to 30 -years at $-20^{\circ} \mathrm{C}$ by rapid phenol-chloroform protocol: a useful tool for genetic epidemiology studies. Mol Cell Probes. 2011;25:44-48. https://doi.org/10.1016/j.mcp.2010.10.003

27. Hide M, Francis DM, Grattan C, Hakimi J, Kochan JP, Greaves MW. Autoantibodies against the high-affinity IgE receptor as a cause of histamine release in chronic 
urticaria. NEJM. 1993;328:1599-1604. https://doi.org/10.1056/ NEJM199306033282204

28. Grattan C, Francis D, Hide M, Greaves M. Detection of circulating histamine releasing autoantibodies with functional properties of anti-lgE in chronic urticaria. Clin Exp Allergy. 1991;21:695-704. https://doi.org/10.1111/j.1365-2222.1991.tb03198.x

29. Guo J, Rapoport B, McLachlan SM. Thyroid peroxidase autoantibodies of IgE class in thyroid autoimmunity. Clin Immunol Immunopathol. 1997;82:157-162. https://doi.org/10.1006/ clin.1996.4297

30. Barrett JC, Clayton DG, Concannon P, Akolkar B, Cooper JD, Erlich HA, et al. Genome-wide association study and meta-analysis find that over 40 loci affect risk of type 1 diabetes. Nat Genet. 2009;41:703. https://doi.org/10.1038/ ng. 381

31. Zheng J, Ibrahim S, Petersen F, Yu X. Meta-analysis reveals an association of PTPN22 C1858T with autoimmune diseases, which depends on the localization of the affected tissue. Genes Immun. 2012;13:641-652. https://doi.org/10.1038/ gene. 2012.46

32. Lee A, Li W, Liew A, Bombardier C, Weisman M, Massarotti E, et al. The PTPN22 R620W polymorphism associates with RF positive rheumatoid arthritis in a dose-dependent manner but not with HLA-SE status. Genes Immun. 2005;6:129-133. https://doi.org/10.1038/sj.gene.6364159

33. Bottini N, Musumeci L, Alonso A, Rahmouni S, Nika K, Rostamkhani $M$, et al. A functional variant of lymphoid tyrosine phosphatase is associated with type I diabetes. Nat Genet. 2004;36:337-338. https://doi.org/10.1038/ng1323

34. Begovich AB, Carlton VEH, Honigberg LA, Schrodi SJ, Chokkalingam AP, Alexander $\mathrm{HC}$, et al. A missense single-nucleotide polymorphism in a gene encoding a protein tyrosine phosphatase (PTPN22) is associated with rheumatoid arthritis. Am J Hum Genet. 2004;75:330-337. https://doi. org $/ 10.1086 / 422827$

35. Rhee I, Veillette A. Protein tyrosine phosphatases in lymphocyte activation and autoimmunity. Nat Immunol. 2012;13:439. https://doi.org/10.1038/ni.2246
36. Cloutier JF, Veillette A. Cooperative inhibition of T-cell antigen receptor signaling by a complex between a kinase and a phosphatase. J Exp Med. 1999;189:111-121. https://doi. org/10.1084/jem.189.1.111

37. Sakaguchi N, Takahashi T, Hata H, Nomura T, Tagami T, Yamazaki S, et al. Altered thymic T-cell selection due to a mutation of the ZAP-70 gene causes autoimmune arthritis in mice. Nature. 2003;426:454-460. https://doi.org/10.1038/nature02119

38. Rieck M, Arechiga A, Onengut-Gumuscu S, Greenbaum C, Concannon P, Buckner JH. Genetic variation in PTPN22 corresponds to altered function of $\mathrm{T}$ and $\mathrm{B}$ lymphocytes. J Immunol. 2007;179:4704-4710. https://doi.org/10.4049/ jimmunol.179.7.4704

39. Vang $T$, Congia $M$, Macis MD, Musumeci L, Orrú V, Zavattari P, et al. Autoimmune-associated lymphoid tyrosine phosphatase is a gain-of-function variant. Nat Genet. 2005;37:1317-1319. https://doi.org/10.1038/ng1673

40. Kessel A, Bishara R, Amital A, Bamberger E, Sabo E, Grushko $G$, et al. Increased plasma levels of matrix metalloproteinase- 9 are associated with the severity of chronic urticaria. Clin Exp Allergy. 2005;35:221-225. https://doi. org/10.1111/j.1365-2222.2005.02168.x

41. Bhattacharyya SP, Drucker I, Reshef T, Kirshenbaum AS, Metcalfe DD, Mekori YA. Activated T lymphocytes induce degranulation and cytokine production by human mast cells following cell-to-cell contact. J Leukoc Biol. 1998;63:337-341. https://doi.org/10.1002/jlb.63.3.337

42. Hidvégi B, Nagy E, Szabó T, Temesvári E, Marschalkó M, Kárpáti $S$, et al. Correlation between T-cell and mast cell activity in patients with chronic urticaria. Int Arch Allergy Immunol. 2003;132:177-182. https://doi.org/10.1159/000073719

43. Auyeung P, Mittag D, Hodgkin PD, Harrison LC. Autoreactive T cells in chronic spontaneous urticaria target the IgE Fc receptor la subunit. J Allergy Clin Immunol. 2016;138:761.e4-768.e4. https://doi.org/10.1016/j.jaci.2016.04.036

44. Kaplan AP. Chronic spontaneous urticaria: pathogenesis and treatment considerations. Allergy Asthma Immunol Res. 2017;9:477-482. https://doi.org/10.4168/aair.2017.9.6.477 